\title{
NEW ANTI-MESOTHELIN SINGLE-DOMAIN ANTIBODIES AND CELL MODELS FOR DEVELOPING TARGETED BREAST CANCER THERAPY
}

Kravchenko YuE, Chumakov SP $\otimes$, Frolova El

Shemyakin-Ovchinnikov Institute of Bioorganic Chemistry of the Russian Academy of Sciences, Moscow, Russia

Most triple negative breast cancers (TNBC) are characterized by elevated expression of mesothelin (MSLN), a cell surface antigen and one of the preferred targets for the therapy of solid tumors. Most continuous TNBC cell lines are MSLN-negative, which obstructs the development of MSLN-targeted therapy for TNBC. The aim of this study was to identify TNBC cell lines with MSLN hyperexpression and to obtain single-domain antibodies (nanobodies) capable of recognizing MSLN in TNBC cells. Mesothelin expression levels were measured in the panel of TNBC cell lines by real-time reverse-transcription PCR. PCR results were verified by measuring concentrations of the megakaryocyte potentiating factor (the secreted fragment of the mesothelin precursor) using sandwich ELISA. Immune phagedisplay VHH fragment libraries were prepared from mononuclear cells of Vicugna pacos using a modified library enrichment protocol. Two nanobody variants with high specificity for the target and $K_{d}$ of about 140 and $95 \mathrm{nmol}$, respectively were obtained. Two MSLN+ and three MSLN- cell lines were identified in the TNBC cell lines panel. The nanobodies demonstrated the ability to recognize the target antigen in MSLN+ cells and had the low ability to bind to MSLN- cells. Thus, we found a convenient MSLN+ TNBC cell model for MSLN-targeted therapy testing. The new single-domain antibodies can be used as targeting components of chimeric antigen receptors.

Keywords: nanobody, chimeric antigen receptor, mesothelin, triple-negative breast cancer

Funding: the study was supported by the Russian Ministry of Education and Science (Project ID RFMEFI60418X0205).

Author contribution: Kravchenko JE — cell culture, real-time PCR and ELISA; Chumakov SP — preparation of immune libraries, protein purification, flow cytometry, manuscript preparation; Frolova El — study design, immunization and blood collection, primary cultures, manuscript preparation.

Compliance with ethical standards: the study was conducted in compliance with the guidelines of the Association for Assessment and Accreditation of Laboratory Animal Care International and the Directive 86/609/EEC dated November 24, 1986.

$\triangle$ Correspondence should be addressed: Stepan P. Chumakov

Miklouho-Maclaya, 16/10, Moscow, 117997; hathkul@gmail.com

Received: 28.09.2020 Accepted: 20.10.2020 Published online: 30.10.2020

DOI: $10.24075 /$ brsmu.2020.068

\section{НОВЫЕ ОДНОДОМЕННЫЕ АНТИТЕЛА К МЕЗОТЕЛИНУ И КЛЕТОЧНЫЕ МОДЕЛИ ДЛЯ РАЗРАБОТКИ ТАРГЕТНОЙ ТЕРАПИИ РАКА МОЛОЧНОЙ ЖЕЛЕЗЫ}

Ю. Е. Кравченко, С. П. Чумаков $џ$, Е. И. Фролова

Институт биоорганической химии имени М. М. Шемякина и Ю. А. Овчинникова, Москва, Россия

Среди случаев трижды негативного рака молочной железы (ТНРМЖ) преобладают новообразования с повышенной экспрессией поверхностного антигена мезотелина (MSLN) - одной из предпочтительных мишеней для направленной терапии многих видов солидных опухолей. Разработка MSLN-опосредованной терапии THPMЖ осложнена тем, что большая часть перевиваемых клеточных культур этого субтипа MSLN-негативны. Целью работы было найти гиперэкспрессирующие MSLN модельные клеточные культуры THРМЖ и получить новые однодоменные антитела (наноантитела), распознающие MSLN на клетках THPMЖ. Уровни транскрипта мезотелина были определены на панели клеточных линий ТНРМЖ при помощи ОТПЦР-РВ, результаты верифицированы непрямым иммуно-ферментным анализом на мегакариоцит-потенцирующий фактор, секретируемую часть белкапредшественника мезотелина. Для получения наноантител адаптировали метод предварительного обогащения иммунных библиотек фрагментов VНHантител из мононуклеаров Vicugna pacos с селекцией при помощи фагового дисплея. В результате исследования получены два варианта наноантител, обладающих высокой специфичностью взаимодействия с мишенью и K около 140 и 95 нмоль. Были идентифицированы две линии клеток MSLN+ и три линии MSLN- THPMЖ. Наноантитела оказались способны распознавать целевой антиген на MSLN+ ${ }^{+}$клетках и обладали низким уровнем связывания с MSLN--клеточными культурами. Установлена удобная клеточная модель MSLN+ THPMЖ для тестирования MSLN-опосредованной терапии; новые однодоменные антитела могут быть использованы в качестве нацеливающих частей химерных антигенных рецепторов.

Ключевые слова: наноантитела, химерный антигенный рецептор, мезотелин, трижды негативный рак молочной железы

Финансирование: работа выполнена при финансовой поддержке Министерства образования и науки РФ (уникальный код проекта RFMEFI60418X0205).

Вклад авторов: Ю. Е. Кравченко - работа с клеточными культурами, ПЦР-РВ, ИФА; С. П. Чумаков - получение иммунных библиотек, проведение селекции, очистка белковых препаратов, цитометрия, написание рукописи; Е. И. Фролова - планирование исследования, проведение манипуляций с животными, работа с первичными культурами, редактирование рукописи

Соблюдение этических стандартов: работу с животными проводили в соответствии с принципами и требованиями Международной лаборатории по уходу за животными и Директивой совета европейских сообществ (86/609/EЕC) от 24 ноября 1986 г.

$\triangle$ Для корреспонденции: Степан Петрович Чумаков

ул. Миклухо-Маклая, 16/10, г. Москва, 117997; hathkul@gmail.com

Статья получена: 28.09.2020 Статья принята к печати: 20.10.2020 Опубликована онлайн: 30.10.2020

DOI: $10.24075 /$ vrgmu.2020.068

Mesothelin (MSLN) is a small cell-surface protein anchored to the cell membrane via its C-terminal glycosylphosphatidylinositol (the GPI-anchor) [1]. In humans, mesothelin expression is limited to the cells that line the pericardium, peritoneum and pleura. However, mesothelin is also abundantly expressed in many tumors, including $100 \%$ of mesotheliomas, up to $70 \%$ of ovarian cancers, $60 \%$ of triple negative breast cancers, $50 \%$ of lung cancers, pancreatic and biliary cancers, and gastric cancer $[2,3]$. The role of mesothelin in the initiation and progression of malignancies is not fully understood. Since mesothelin is a receptor for another cancer antigen, MUC16, it might promote the metastatic expansion of MUC16-expressing cells typically 
seen in ovarian tumors [4]. Mesothelin can inhibit the TNF $\alpha$ induced apoptosis of tumor cells [5], stimulate proliferation and invasion of malignant cells [6] and promote resistance to chemotherapy [7]. The evident prooncogenic effect of this protein, its elevated expression in the most aggressive subpopulations of cancer cells and limited expression in normal tissue make mesothelin an attractive target for cancer therapies that rely on monoclonal antibodies and immunocompetent cells expressing chimeric antigen receptors (CARs). Currently, a few types of immunotoxins and MSLN-CAR-T cells are being tested as candidate therapeutics against mesotheliomas, pancreatic, biliary, gastric and ovarian cancers [3].

Mesothelin can function as a biomarker for many TNBC [8]. TNBC is defined as a breast cancer negative for the estrogen (ER) and progesterone (PR) receptors and lacking HER2/neu (ERBB2) expression. TNBC is a very aggressive malignancy with a poor prognosis: there are no effective therapeutic regimens for this type of cancer. There were attempts to identify different gene expression patterns within this cancer subtype; for example, the claudin-low phenotype was identified a while ago [9]. This, however, did not result in the advent of a novel specific therapy for TNBC. Mesothelin is overexpressed in more than half of TNBC cases and in no more than $4 \%$ of $\mathrm{ER}^{+}, \mathrm{PR}^{+}$and $\mathrm{ERBB}^{+}$breast cancers; therefore, it could be considered a fairly selective TNBC marker and a promising therapeutic target [10].

In MSLN-targeted CAR-based therapy, the antigenrecognition domain of $\mathrm{CAR}$ is assembled from single-chain variable fragments (scFv) derived from anti-MSLN monoclonal antibodies [11]. This is a fast yet not perfect method for obtaining CAR prototypes and testing their efficacy. ScFv derived from traditional antibodies can have inferior physical and chemica properties due to the altered secondary structure and are characterized by reduced affinity and reduced specificity for the target protein [12]. Besides, it is argued that monoclonal antibodies for immunotherapy and immunodiagnostics should preferably be high-affinity (in the nanomolar range), whereas the most important factor for CAR engineering is antibody binding specificity (the optimal antibody affinity for the target can be much lower) [13]. This necessitates a search for new antibodies for CAR constructs.

Since antibodies for CAR therapy are designed as ScFv, alternative immunoglobulin structures like single-domain antibodies (sdAb) of Camelidae have some advantages as candidates for CAR design [14]. These camelid antibodies consisting of variable heavy homodimers $(\mathrm{VHH})$ arose from a point mutation in the hinge region of the heavy chain; in the course of evolution, they "learnt" to effectively recognize antigens in the absence of light chain variable fragments [15] Owing to the extended CDR3 length and the presence of an additional disulfide bond, $\mathrm{VHH}$ antibodies are capable of binding to their targets with the same specificity and affinity as traditional antibodies, but they are advantageously smaller in size and have good solubility. Their antigen-recognition sites are located on their single peptide chain, so they can be easily employed as scFv ( $\mathrm{VHH}$ fragments or nanobodies) to create new CARs [16]. Today, there are two variants of antimesothelin nanobodies, but their application is still limited to immunodiagnostics [17, 18].

Once the antigen-recognition domain of an anti-MSLN CAR has been designed, the CAR construct needs to be tested using an adequate ex vivo model. According to the literature, the most commonly exploited model TNBC cell lines are MSLN-. The aim of this study was to identify the cell line with high MSLN expression in the panel of commercial TNBC cell lines, select $\mathrm{VHH}$ fragments against MSLN using phage display and find a few sequence variants that could be used to create an anti-MSLN CAR.

\section{METHODS}

\section{Cell culture}

The cell lines used in this study, including HEK-293T (transformed human cells), MDA-MB-231, MDA-MB-468, MDA-MB-436, MDA-MB-157, MDA-MB-453, HCC1937, HCC1143, HCC38, HCC70, HCC1806, HCC1187, HCC1395, BT-549, BT-20, and Hs 578T (TNBC), were ordered from the American Type Culture Collection (ATCC; USA). The cells were grown in DMEM-F12 (PAA; Austria) supplemented with 10\% fetal bovine serum (Gibco; USA), $2 \mathrm{mM}$ alanylglutamine (PanEco; Russia), $20 \mathrm{mM} \mathrm{HEPES,} 100 \mu \mathrm{g} / \mathrm{ml}$ penicillin and 100 mg/ml streptomycin (PanEco; Russia).

\section{RNA isolation and reverse transcription PCR}

RNA was isolated using an RNeasy Mini kit and spin columns (Qiagen; USA) following the manufacturer's protocol or, alternatively, extracted in preparative amounts using an ExtractRNA reagent (Evrogen; Russia) following the manufacturer's protocol. The reverse cDNA sequence was generated from the purified RNA template using a ProtoScript II First Strand cDNA Synthesis Kit (NEB; USA). The purified RNA (500 ng per reaction) was mixed with other kit components, including the $\mathrm{d}(\mathrm{T})_{23}$ primer, following the manufacturer's protocol. CDNA of $\mathrm{VHH}$ fragments was synthesized using a specific primer CH2-lgG-sp rev (GGTACGTGCTGTTGAACTGTTCC). The RNA/primer mix was incubated at $42{ }^{\circ} \mathrm{C}$ for one hour and then at $80^{\circ} \mathrm{C}$ for $5 \mathrm{~min}$. The amount of cDNA per each quantitative PCR (qPCR) reaction was no more than $50 \mathrm{ng}$.

\section{Real-time PCR}

For qPCR, we used HS-Taq polymerase (Evrogen; Russia) and a set of specific primers, including MSLN-qPCR dir (GCACTCCTCTTTCTGCCTGG), MSLN-qPCR rev (GCCATGGTCTGTGTAGATCCC) and MSLN-probe (5'-FAMCCCACGGTGCCTCCCTCCCT-BHQ1-3') by DNA-synthesis, Russia. Primer and probe selection was aided by the PrimerBLAST tool (NIH NCBI; USA). Prediction of secondary structures was carried out using the OligoAnalyzer Tool (IDT; USA). All experiments were run in 6 replicates. The amount of the accumulated PCR product was compared between the samples based on the Ct values. GAPDH was used as an internal control for real-time PCR; the expression of target genes was normalized to GAPDH expression ( $\triangle \mathrm{Ct}$ ). The $\triangle \mathrm{Ct}$ value in the CDNA sample isolated from the MDA-MB-231 cell line was used as a calibration standard. Thus, changes in gene expression in the studied samples were calculated by the formula: 2 - ( $\Delta$ Ctsample - $\Delta$ Ctcalib) [19]. PCR was performed in the MyiQ Single-Color Real-Time PCR Detection System (Bio-rad; USA).

\section{MSLN producer and recombinant protein}

CDNA prepared from the HCC1806 cell line was amplified in the presence of 2 primers for the membrane-anchored mesothelin domain sequence: MSLN full dir (GAAGTGG AGAAGACAGCCTGTCCTTCAGGC) and MSLN full rev (GCTGAGGTCTAGGACCAGGTAGCCGTTG) by DNAsynthesis, Russia. The initial denaturation step was performed at $95^{\circ} \mathrm{C}$ for $120 \mathrm{~s}$, followed by 30 cycles of $95^{\circ} \mathrm{C}$ for $30 \mathrm{~s}, 66^{\circ} \mathrm{C}$ 
for $30 \mathrm{~s}$ and $72{ }^{\circ} \mathrm{C}$ for $60 \mathrm{~s}$ in the presence of Tersus polymerase (Evrogen; Russia). Then the reaction mix was loaded on $1 \%$ agarose gel and stained with the intercalating Sybr Gold dye (Thermo; USA); the target band ( 890 bp) was identified using the Cleanup mini kit (Evrogen; Russia). The obtained DNA was subjected to PCR amplification in the presence of 2 primers: MSLN Xba dir (AGAGAGTCTAGAGAAGTGGAGAAGACAG CCTGTCCTTCAGGC) and MSLN Bglll rev (AGAGAGAGATC TGCTGAGGTCTAGGACCAGGTAGCCGTTG), following the protocol of 18 cycles described above. The PCR product was again purified using the Cleanup mini kit and cloned at the $\mathrm{Xbal}$ - Bglll/BamHI restriction sites (enzymes by NEB; USA) of a pLCMV-HT-puro lentiviral expression vector (ligase T4, Evrogen; Russia). Plasmid pLCMV-MSLN-HT-puro DNA was purified using a Plasmid miniprep kit (Evrogen; Russia). To prepare the lentiviral vector, 106 HEK-293T cells were plated onto a $10 \mathrm{~cm}$ culture dish. Next day, the LCMV-MSLN-HT-puro plasmid was mixed with the psPAX2 and PMD2.G packaging plasmids (both were a gift from Didier Trono (Addgene plasmid \# 12260 ; http://n2t.net/addgene:12260 ; RRID:Addgene_12260 and Addgene plasmid \# 12259 ; http://n2t.net/addgene:12259; RRID:Addgene_12259) at the weight ratio of $5: 3: 2$ (the total amount was $20 \mu \mathrm{g})$. Transfection was performed in the OptiMEM medium (Gibco; USA) following the protocol adapted from [20]. Next day, the Opti-MEM medium was replaced with fresh serum-free DMEM-F12 supplemented with a Serum replacement solution, a Lipid mixture (both by Peprotech; USA) and $4 \mathrm{mM}$ caffeine (Sigma Aldrich; USA). Forty-eight hours later, the medium enriched in the lentivirus was harvested, filtered, supplemented with $10 \mu \mathrm{g} / \mathrm{ml}$ polybrene (Sigma Aldrich; USA) and combined with intact HEK-293T cells $\left(5 \times 10^{5}\right)$ plated onto a $10 \mathrm{~cm}$ culture dish. After $24 \mathrm{~h}$ of incubation, the medium was replaced with a regular culture medium. Seventy-two hours after inoculation, the medium was supplemented with $1 \mu \mathrm{g} / \mathrm{ml}$ puromycin (Sigma Aldrich; USA), and the culture was left to incubate for 10 days. To obtain recombinant mesothelin, the cells were seeded onto six $15-\mathrm{cm}$ culture dishes $\left(2.5 \times 10^{7}\right.$ cells per dish) containing DMEM-F12 supplemented with the Serum replacement solution and the Lipid mixture. Protein-containing liquid culture medium was harvested every 4 days for 16 days. The obtained recombinant mesothelin was purified on HIS Mag Sepharose Excel magnetic beads (Cytiva; USA) according to the manufacturer's protocol. Pooled mesothelin samples were run through PD-10 columns (Cytiva; USA) to transfer mesothelin to a phosphate buffer. Mesothelin concentrations were determined by measuring OD280 with a Nanodrop OneC spectrophotometer (Thermo; USA). For quality control, the protein was run in a polyacrylamide gel and stained with Coomassie Blue G-250 following the standard protocol.

\section{Animal immunization and collection of biological samples}

Biological specimens (venous blood samples) were collected from an alpaca (Vicugna pacos), the member of the Camelidae family. For primary immunization, $400 \mu \mathrm{g} / 500 \mu \mathrm{l}$ mesothelin was mixed with an equal volume of complete Freund's adjuvant (Pierce; USA) until complete homogenization. For boosting, $250 \mu \mathrm{g} / 500 \mu \mathrm{l}$ mesothelin was combined with an equal volume of incomplete Freund's adjuvant. A total of 3 booster doses were administered at 2-week intervals. The antigen was injected subcutaneously and intramuscularly into the thigh of the animal. Prior to each immunization, a venous blood sample $(10 \mathrm{ml})$ was collected to measure serum concentration of antimesothelin antibodies. B cells were separated from peripheral blood mononuclear cells (PBMC) 5 days after the last booster injection. PBMC were isolated from a fresh blood sample $(100 \mathrm{ml})$ by density gradient centrifugation with Ficoll $(1,077 \mathrm{~g} / \mathrm{ml})$ (PanEco; Russia) following the standard protocol.

\section{Primary selection of B cells}

Recombinant mesothelin was biotinylated with NHS-LCbiotin (Covachem; USA) following the standard protocol and then used for magnetic separation of B cells with an EasySep Biotin Positive Selection Kit II (Stemcell Technologies; Canada) according to the manufacturer's protocol. RNA was isolated from the separated cell fraction using the Satellite red coprecipitator (Evrogen; Russia).

\section{Assembly of immune VHH library}

The $\mathrm{VHH}$ library was prepared from cDNA synthesized in 8 independent reactions from a total of $4 \mu \mathrm{g}$ mRNA. Target $\mathrm{VHH}$ sequences were amplified in the presence of high-fidelity Tersus polymerase (Evrogen; Russia) and the following primers: AlpVHH3 uni fwd (CCACCATGTCTAGASAGKTGCAGSTSGTR GAGTCTGKGGGAGG), AlpVHH-R1 (AATCCGGATCCGGGGG GTCTTCGCTGTGGTGCG) and AlpVHH-R2 (AATCCGGATCC GGTTGTGGTITGGTGTCTTGGG); the 2 later primers were based on the sequences published in [21]. The amplification protocol consisted of a denaturation step at $95^{\circ} \mathrm{C}$ for $120 \mathrm{~s}$, followed by 30 cycles of $95^{\circ} \mathrm{C}$ for $30 \mathrm{~s}, 61^{\circ} \mathrm{C}$ for $30 \mathrm{~s}$ and $72^{\circ} \mathrm{C}$ for $30 \mathrm{~s}$. The phagemid library was prepared by cloning the amplified VHH sequences into a pHEN2-XB phagemid using the $\mathrm{Xbal}$ and BamHI-HF endonucleases and the T4 Electroligase (NEB; USA). TG-1 cells were transformed with the phagemid library by electroporation using a Genepulser system (Bio-Rad; USA). Phage selection was performed following a previously published protocol [22] using the antigen immobilized on immuno tubes.

\section{Expression and purification of candidate biotinylated antibodies}

Sequences of $\mathrm{VHH}$ fragments from the selected individual phagemid clones were cloned into the pET-BAD expression vector at the $\mathrm{Xbal}$ and $\mathrm{BamHI}$ sites. The resultant constructs were used to transform biotin ligase-expressing BL21DE3BirA cells. The water-soluble nanobodies were obtained from individual cell colonies grown in the liquid medium supplemented with 0.2 mM D-biotin (Covachem; USA). The culture protocol was previously described in [23]. The watersoluble nanobodies were isolated from the periplasm by lysing the bacterial cell sediment in the buffer composed of $50 \mathrm{mM}$ Tris- $\mathrm{HCl}(\mathrm{pH} 7.4), 150 \mathrm{mM} \mathrm{NaCl}, 0,1 \%$ Triton $\mathrm{X}-100$ and $10 \mathrm{mg} / \mathrm{ml}$ lysozyme and PMSF, followed by triple sonication with a Soniprep-100 ultrasonic disintegrator (Soniprep; USA), subsequent purification on HIS Mag Sepharose Excel magnetic beads (Cytiva; USA) and transfer to a phosphate buffer.

\section{ELISA}

Megakaryocyte potentiating factor (MPF) concentrations in the liquid culture media were measured using a Human Mesothelin Propeptide/MPF DuoSet ELISA (RND Systems; USA) according to the manufacturer's protocol. To quantify anti-mesothelin serum antibodies, the collected serum samples were added to the wells of a well-plate coated with $5 \mu \mathrm{g} / \mathrm{ml}$ mesothelin and then treated with polyclonal sheep anti-alpaca antibodies; detection was carried out using HRP-conjugated donkey anti- 
sheep antibodies (Santa Cruz; USA). Library enrichment was evaluated following a previously published protocol [22]. The wells of the well-plate were coated with $5 \mu \mathrm{g} / \mathrm{ml}$ mesothelin; detection was aided by HRP-conjugated anti-M13 antibodies (Sino Biological; China). For direct ELISA, the wells of the well-plate were coated with mesothelin and treated with $1 \mathrm{\mu g} / \mathrm{ml}$ nanobodies. Antigen detection was carried out using anti-c-myc biotinylated antibodies (SciStoreLab; Russia) and HRP-conjugated streptavidin (R\&D Systems; USA) or, for biotinylated nanobodies, using HRP-conjugated streptavidin only. For sandwich ELISA, $5 \mu \mathrm{g} / \mathrm{ml}$ MesoVHH-1E3 was used as a capture antibody for antigen immobilization, $1 \mathrm{mg} / \mathrm{ml}$ MesoVHH-2H5B was used as a detection antibody, and HRPconjugated streptavidin was added for additional probing. A ready-to-use tetramethylbenzidine solution (Sigma Aldrich; USA) was employed as a substrate for HRP conjugates. Colorimetric measurements were done with a Triad microplate reader (Dynex; USA).

\section{Biolayer interferometry}

Dissociation constants $(\mathrm{Kd})$ for purified MesoVHH-1E3B and MesoVHH-2H5B nanobodies were determined using Streptavidin (SA) biosensors and a BLItz system (ForteBio; USA).

\section{Nanobody cell staining and flow cytometry}

Adherent cells were detached from the surface using TrypLE (Thermo; USA) and then fixed in 3.7\% paraformaldehyde solution. Cells suspended in the phosphate buffer were incubated with $5 \mu \mathrm{g} / \mathrm{ml}$ nanobodies for one hour (except for control samples) and then washed with Streptavidin-FITC (MyBioSource; USA) for 40 min. After that, the unreacted reagent was removed and fluorescence was measured by means of a FacsVantage SE flow cytometer (Beckton Dickinson; USA). The data generated by flow cytometry were processed in Flowing Software (Perttu Terho; Finland).

\section{Statistical analysis}

Statistical analysis was done in Prism 8 software (GraphPad Software; USA).

\section{RESULTS}

To obtain nanobodies against mesothelin, a Vicugna pacos animal was challenged with recombinant mesothelin containing highly immunogenic full-sized regions II and III. The immune response was closely monitored at all time points after initial immunization and administration of booster doses. Production of anti-mesothelin serum antibodies slowed between the $2^{\text {nd }}$ and $3^{\text {rd }}$ booster injections (Fig. 1A), so blood samples for library preparation were collected on day 5 after the $3^{\text {rd }}$ booster injection. The mononuclear cell fraction was divided into 2 equal parts, which were subsequently used to prepare 2 immune phage-display libraries. The first library was prepared from the total RNA isolated from mononuclear cells; the second library was prepared from the total RNA isolated from the cells that had undergone positive selection on magnetic beads coated with biotinylated mesothelin. This was necessary to clear the cell population of the B cells that secreted irrelevant antibodies. Both phage-display libraries were subjected to 3 rounds of selection on the immobilized antigen, with enrichment control between the rounds. The second library was characterized by higher abundance of MSLN-reactive clones and better enrichment with target sequences after as early as one round of selection (Fig. 1B). After positive selection, 48 clones were randomly chosen from each library and tested for response to mesothelin using ELISA; the clones characterized by the maximum level of signal intensity (Fig. 1C) were sequenced.

Sequencing revealed that all selected clones contained 2 types of $\mathrm{VHH}$ fragments, which we called MesoVHH-1E3 and MesoVHH-2H5.
A

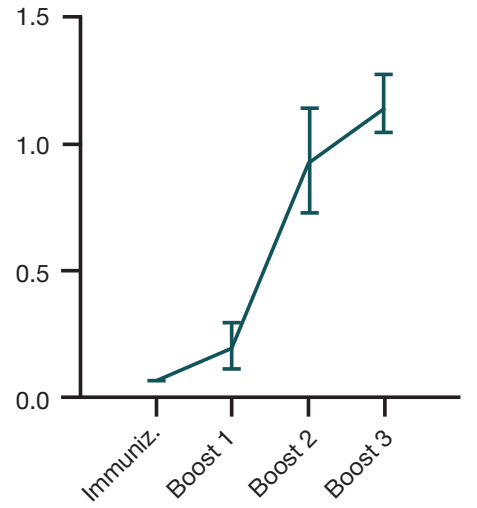

B

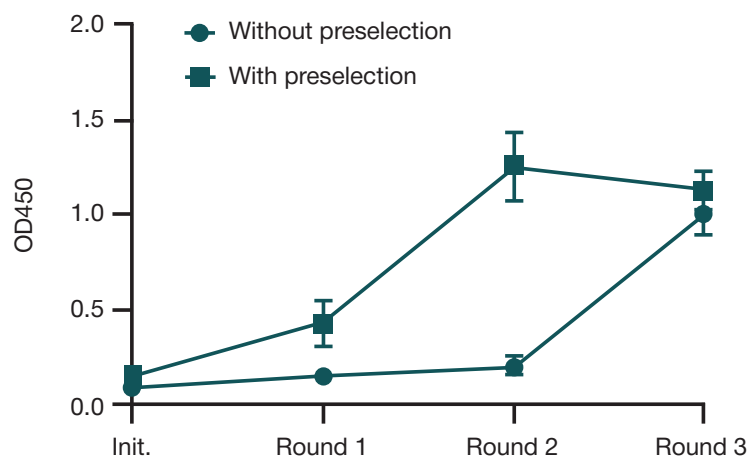

C

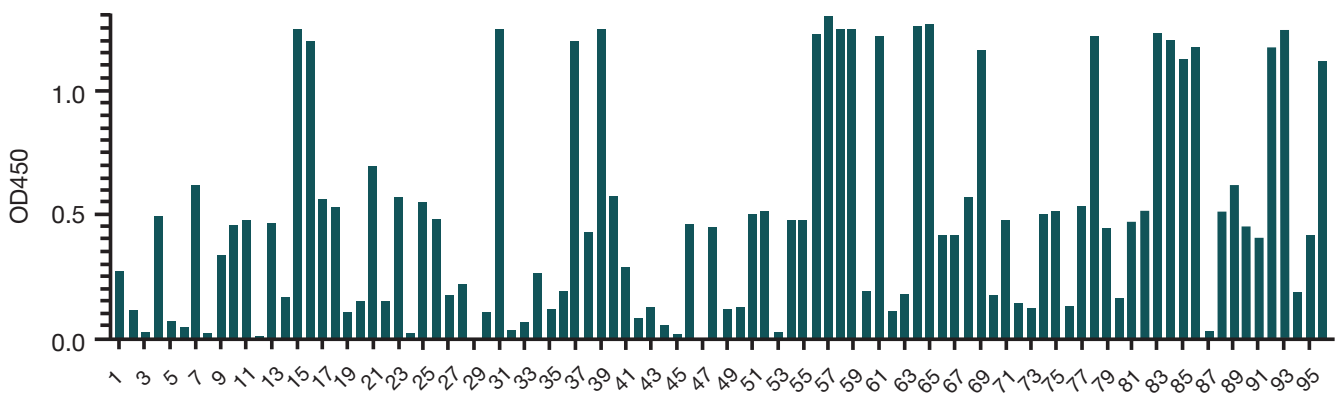

Fig. 1. Selection of nanobodies. A. Levels of anti-mesothelin serum antibodies in the blood of the immunized animal at the time of immunization and each booster injection. B. The dynamics of phage libraries enrichment with mesothelin-specific nanobodies after each round of selection. C. Results of screening of 96 randomly selected clones (direct ELISA for mesothelin). 1-48 — clones from the library that was not subjected to preselection; 49-96 — clones from the library that underwent preselection. 
A

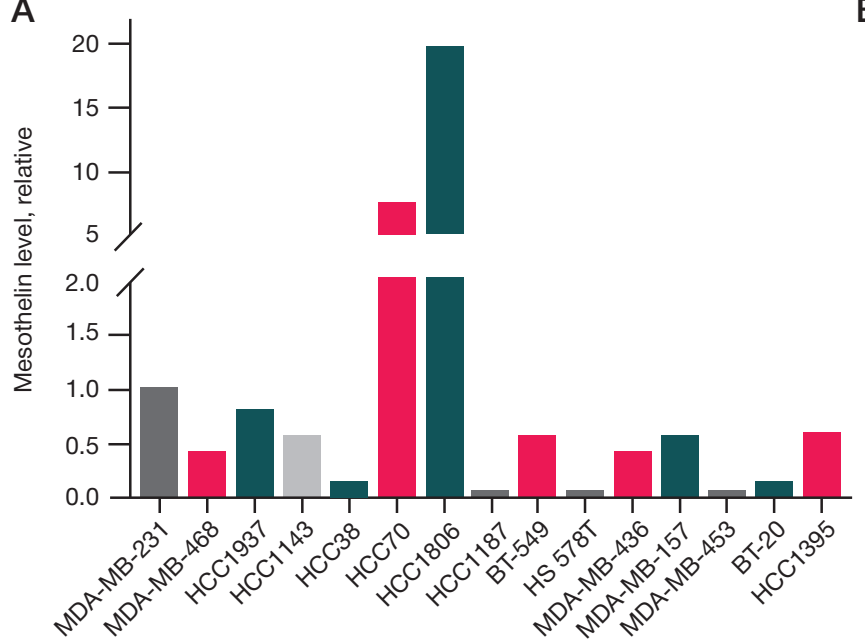

B

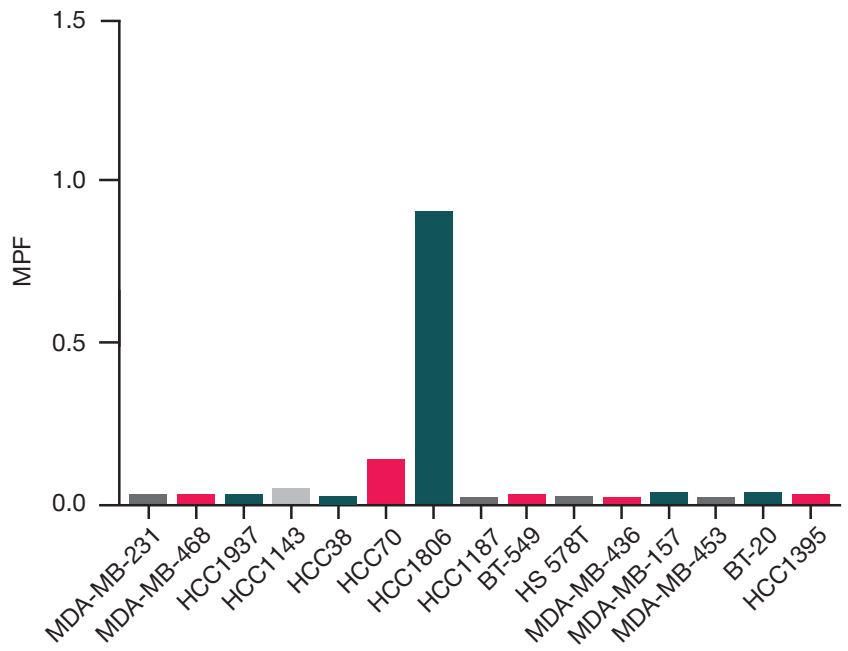

Fig. 2. Determination of mesothelin levels. A. Relative MSLN expression levels in TNBC cell lines evaluated by real-time PCR. B. MPF levels in the cultural media with TNBC. The graphs show median values and standard deviations between biological replicates

Both sequences were cloned into a pET-BAD expression vector in frame with biotinylation signal sequence of BirA biotin ligase. Biotinylated MesoVHH-1E3B and MesoVHH-2H5B antibodies purified by means of affinity chromatography were tested for their ability to bind to mesothelin using ELISA. We also attempted indirect antigen detection, in which MesoVHH$1 \mathrm{E} 3$ was used as a capture antibody and MesoVHH-2H5B was used as a detection antibody. Both tests were successful. Then, dissociation constants were determined for the purified antibodies by means of biolayer interferometry. For MesoVHH$1 \mathrm{E} 3 \mathrm{~B}, \mathrm{Kd}$ was approximating $140 \mathrm{nmol}$, whereas for MesoVHH$2 \mathrm{H} 5 \mathrm{~B}$ it was about $95 \mathrm{nmol}$.

Mesothelin expression was measured in the panel of TNBC cell lines by real-time PCR in order to identify MSLN ${ }^{+}$ and $\mathrm{MSLN}^{-}$cultures. The data generated by real-time PCR were normalized to the MDA-MB-231 cell line characterized by low mesothelin expression. The analysis showed that low mesothelin expression was typical for most of the tested TNBC cell lines (Fig. 2). Two cell lines (HCC70 and HCC1806) exhibited moderate expression and hyperexpression of MSLN, respectively, and therefore were chosen as model cell lines for further tests on the selected candidate anti-MSLN $\mathrm{VHH}$ antibodies. By contrast, the HCC1187, Hs 578T and MDA-MB-453 cell lines were characterized by significantly (> tenfold) reduced MSLN expression and therefore were chosen as negative controls. The levels of intracellular transcripts do not always correlate with the actual amount of the protein on the cell surface, so the results of real-time PCR needed to be verified by ELISA using a secreted fragment of the mesothelin precursor MPF. Only 2 cell lines (HCC70 and HCC1806) were found to secrete MPF into the liquid culture medium after 6 days of incubation (Fig. 2B); MPF levels were well-correlated with the levels of mesothelin expression measured by real-time PCR.

Purified MesoVHH-1E3B and MesoVHH-2H5B antibodies were used to stain the selected cell cultures and perform flow cytometry. Both $\mathrm{VHH}$ fragments produced intense fluorescence in most cells (\%) of the HCC1806 and HCC70 cell populations (Fig. 3); however, fluorescence was much less intense in HCC70 cells. No significant differences were observed between the histograms constructed for the MDA-MB-453, HCC1187 and $\mathrm{Hs} 578 \mathrm{~T}$ cell lines that were used as a negative control to test the non-specific binding of the studied nanobodies and the histograms of corresponding samples that were not labeled with $\mathrm{VHH}$ fragments. These findings were consistent with the PCR data on mesothelin expression in TNBC cell lines used for the testing of $\mathrm{VHH}$ fragments. This suggests that the studied nanobodies had high specificity for the target antigen.

\section{DISCUSSION}

We have successfully identified two specific single-domain antibodies against mesothelin. The protocol for the pre-

A
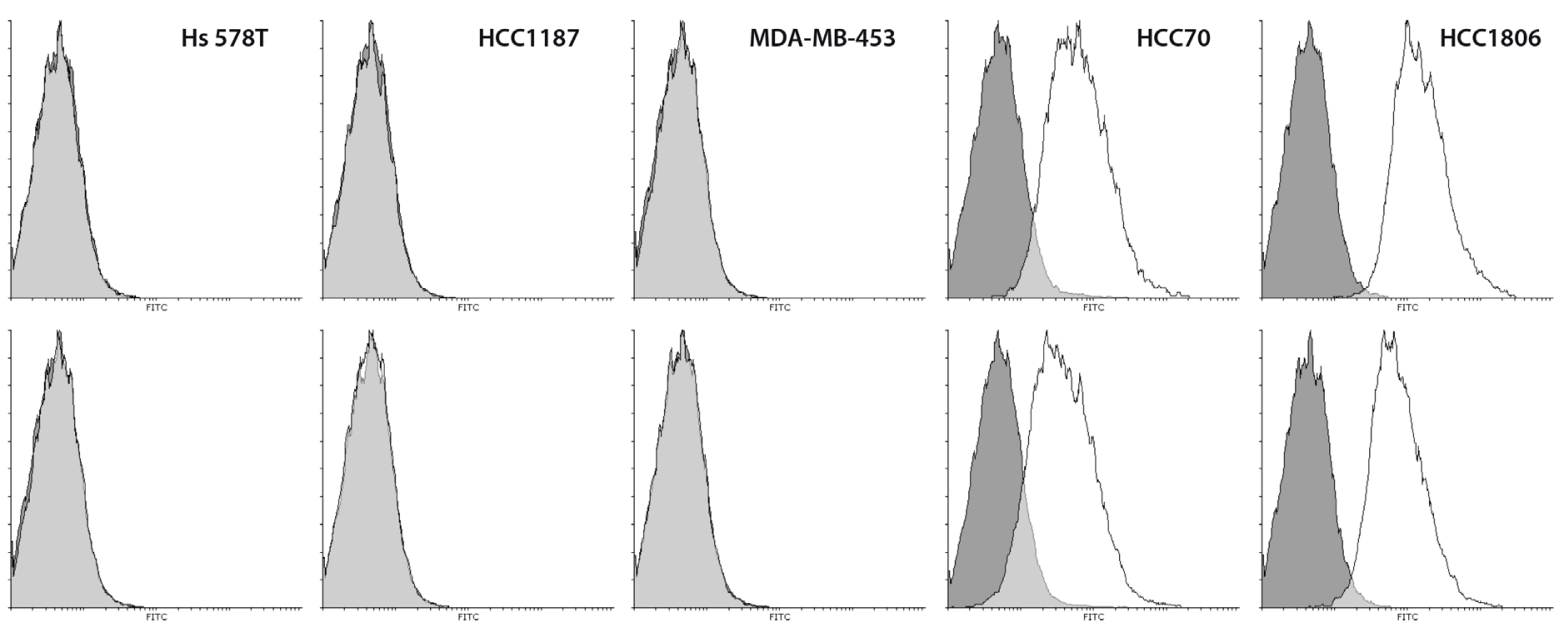

Fig. 3. Testing of the nanobodies in TNBC cell lines. The graphs show flow cytometry results for the model TNBC cell lines labeled with MesoVHH-2H5B (A) and MesoVHH-1E3B (B). Staining was done with Streptavidin-FITC 
selection of immunocompetent cells was adapted from [24] and used to prepare immune libraries. Unlike the original protocol, we did not perform negative selection on magnetic beads to separate the B-cell fraction from mononuclear peripheral cells due to the absence of commercial kits for the isolation of alpaca B cells. The step involving the sorting of B cells labeled with fluorescently-conjugated antibodies was also skipped. Instead, we decided to isolate $\mathrm{B}$ cells expressing target $\mathrm{B}$-cell receptors on their surface by performing positive selection on magnetic beads coated with biotinylated mesothelin. This approach allowed us to reduce the amount of the initial raw material 100 -fold and create a smaller phage library devoid of irrelevant antibody fragments. Both anti-MSLN nanobodies were more abundant in the preselected library and were detected during the screening of individual clones as early as the first round of selection. We conclude that our simplified preselection procedure takes 3 times less time than usually needed to select a candidate clone. The relative abundance of clones with affinity for the target in the initial library can prevent the loss of rare sequences with unique properties.

Currently, there are a few known variants of anti-mesothelin $\mathrm{VHH}$ antibodies [17, 18]. These nanobodies show promise as immunodiagnostic tools, targeting molecules for nanoparticlebased therapy and components of bispecific therapeutic agents. The nanobodies identified in this study are slightly inferior to the already known nanobodies in terms of their specificity; however, this parameter is not definitive in allowing the use of a $\mathrm{VHH}$ fragment in a CAR construct. MesoVHH-1E3 and MesoVHH-2H5B have been successfully tested as capture and detection antibodies, respectively, in a sandwich ELISA. This suggests that the two nanobodies recognize different mesothelin epitopes and their simultaneous binding to the target is not impeded.

Mesothelin-targeting CARs are being actively tested as candidate therapies for solid tumors [3]. Recently, a number of studies have been published on the MSLN-targeted therapy for TNBC [10]. There is a need for a convenient MSLN+ TNBC cell model that could be employed for testing these therapeutic approaches ex vivo and in vivo. Although the proportion of primary MSLN ${ }^{+}$TNBC cultures is substantial, the continuous cell lines of this subtype are mostly MSLN-negative [8]. By screening the wide panel of TNBC cell lines, we were able to identify 2 candidate cell models and 3 cell lines with suppressed MSLN expression. For $\mathrm{MSLN}^{+}$-cell lines, real-time PCR results were consistent with the results of ELISA assays for the MPF, the secreted fragment of the mesothelin precursor present in the cell supernatant. Noteworthy, both $\mathrm{MSLN}^{+}$-cell lines can be used to induce cancer in immunodeficient BalbC/nude [25, 26] via an orthotopic injection, which makes this cell model suitable for in vivo experiments.

The selected anti-mesothelin nanobodies were tested on the MSLN ${ }^{+}$TNBC model and demonstrated the ability to recognize the native TNBC antigen. The low level of background signal in the MSLN+ ${ }^{+}$cell lines stained with the nanobodies indicates their high specificity for the target. The obtained data leads us to hypothesize that MesoVHH-1E3 and MesoVHH-2H5 might be used to create compact functionally active antigen receptors for mesothelin.

\section{CONCLUSIONS}

Using a modified protocol for the preselection of cells obtained from an immunized animal, we identified 2 nanobodies capable to specifically bind to mesothelin. The activity of these nanobodies was demonstrated in the in vitro experiment. The identified $\mathrm{VHH}$ fragments recognize different non-overlapping epitopes of MSLN and can be used for sandwich ELISA. Using biolayer interferometry, we determined the $K_{d}$ values for MesoVHH-1E3B and MesoVHH-2H5B (about 140 and 95 nmol, respectively). The panel of TNBC cell lines was screened for candidate MSLN ${ }^{+}$cell models, and 2 cell lines (HCC1806 and HCC70) were chosen as characterized by high and moderate hyperexpression of mesothelin. We also identified 3 cell lines (HCC1187, Hs 578T and MDA-MB-453) in which mesothelin expression was suppressed. The selected antimesothelin nanobodies were able to specifically stain native mesothelin on the surface of HCC1806 and HCC70 cells and had low levels of non-specific binding in MSLN- breast cancer lines. Our findings suggest that the MesoVHH-1E3 and MesoVHH-2H5 nanobodies could be used for the molecular diagnosis of tumors and creation of compact and functionally active antigen receptors for mesothelin.

\section{References}

1. Pastan I, Hassan R. Discovery of mesothelin and exploiting it as a target for immunotherapy. Cancer Res. 2014; 74 (11): 290712. DOI: 10.1158/0008-5472.CAN-14-0337. PubMed PMID: 24824231

2. Einama T, Homma S, Kamachi H, Kawamata F, Takahashi K, Takahashi $\mathrm{N}$, et al. Luminal membrane expression of mesothelin is a prominent poor prognostic factor for gastric cancer. $\mathrm{Br} J$ Cancer. 2012; 107 (1): 137-42. DOI: 10.1038/bjc.2012.235. PubMed PMID: 22644300.

3. Kelly RJ, Sharon E, Pastan I, Hassan R. Mesothelin-targeted agents in clinical trials and in preclinical development. Mol Cancer Ther. 2012; 11 (3): 517-25. DOI: 10.1158/1535-7163.MCT-110454. PubMed PMID: 22351743.

4. Rump A, Morikawa Y, Tanaka M, Minami S, Umesaki N, Takeuchi M, et al. Binding of ovarian cancer antigen CA125/MUC16 to mesothelin mediates cell adhesion. J Biol Chem. 2004; 279 (10): 9190-8. DOI: 10.1074/jbc.M312372200. PubMed PMID: 14676194.

5. Bharadwaj U, Marin-Muller C, Li M, Chen C, Yao Q. Mesothelin confers pancreatic cancer cell resistance to TNF-alpha-induced apoptosis through Akt/PI3K/NF-kappaB activation and IL-6/Mcl-1

overexpression. Mol Cancer. 2011; 10: 106. DOI: 10.1186/14764598-10-106. PubMed PMID: 21880146.

6. Li M, Bharadwaj U, Zhang R, Zhang S, Mu H, Fisher WE, et al Mesothelin is a malignant factor and therapeutic vaccine target for pancreatic cancer. Mol Cancer Ther. 2008; 7 (2): 286-96. DOI: 10.1158/1535-7163.MCT-07-0483. PubMed PMID: 18281514.

7. Cheng WF, Huang CY, Chang MC, Hu YH, Chiang YC, Chen YL, et al. High mesothelin correlates with chemoresistance and poor survival in epithelial ovarian carcinoma. Br J Cancer. 2009; 100 (7): 1144-53. DOl: 10.1038/sj.bjc.6604964. PubMed PMID: 19293794.

8. Wang M, Li A, Sun G, Mbuagbaw L, Reid S, Lovrics PJ, et al. Association between mesothelin expression and survival outcomes in patients with triple-negative breast cancer: a protocol for a systematic review. Syst Rev. 2016; 5 (1): 133. DOI: 10.1186/ s13643-016-0313-6. PubMed PMID: 27514374.

9. Fougner C, Bergholtz H, Norum JH, Sorlie T. Re-definition of claudin-low as a breast cancer phenotype. Nat Commun. 2020; 11 (1): 1787. DOI: 10.1038/s41467-020-15574-5. PubMed PMID: 32286297

10. Tchou J, Wang LC, Selven B, Zhang H, Conejo-Garcia J, Borghaei $\mathrm{H}$, et al. Mesothelin, a novel immunotherapy target for 
triple negative breast cancer. Breast Cancer Res Treat. 2012; 133 (2): 799-804. DOI: 10.1007/s10549-012-2018-4. PubMed PMID: 22418702

11. Lanitis E, Poussin M, Hagemann IS, Coukos G, Sandaltzopoulos R, Scholler N, et al. Redirected antitumor activity of primary human lymphocytes transduced with a fully human anti-mesothelin chimeric receptor. Mol Ther. 2012; 20(3): 633-43. DOI: 10.1038/ mt.2011.256. PubMed PMID: 22127019.

12. Fujiwara K, Masutani M, Tachibana M, Okada N. Impact of scFv structure in chimeric antigen receptor on receptor expression efficiency and antigen recognition properties. Biochem Biophys Res Commun. 2020; 527 (2): 350-7. DOI: 10.1016/j. bbrc.2020.03.071. PubMed PMID: 32216966.

13. Maus MV, Plotkin J, Jakka G, Stewart-Jones G, Riviere I, Merghoub T, et al. An MHC-restricted antibody-based chimeric antigen receptor requires TCR-like affinity to maintain antigen specificity. Mol Ther Oncolytics. 2016; 3: 1-9. DOI: 10.1038/ mto.2016.23. PubMed PMID: 29675462.

14. Tillib SV. Prospective Applications of Single-Domain Antibodies in Biomedicine. Mol Biol (Mosk). 2020; 54 (3): 362-73. Epub 2020/06/04. DOI: 10.31857/S0026898420030167. PubMed PMID: 32492000

15. Hamers-Casterman C, Atarhouch T, Muyldermans S, Robinson G, Hamers C, Songa EB, et al. Naturally occurring antibodies devoid of light chains. Nature. 1993; 363 (6428): 446-8. DOI: 10.1038/363446a0. PubMed PMID: 8502296.

16. Liu W, Song $\mathrm{H}$, Chen Q, Yu J, Xian M, Nian R, et al. Recent advances in the selection and identification of antigen-specific nanobodies. Mol Immunol. 2018; 96: 37-47. DOI: 10.1016/j. molimm.2018.02.012. PubMed PMID: 29477934

17. Prantner AM, Turini M, Kerfelec B, Joshi S, Baty D, Chames P, et al. Anti-Mesothelin Nanobodies for Both Conventional and Nanoparticle-Based Biomedical Applications. J Biomed Nanotechnol. 2015; 11 (7): 1201-12. DOI: 10.1166/ jbn.2015.2063. PubMed PMID: 26307843.

18. Prantner AM, Yin C, Kamat K, Sharma K, Lowenthal AC, Madrid PB, et al. Molecular Imaging of Mesothelin-Expressing Ovarian
Cancer with a Human and Mouse Cross-Reactive Nanobody. Mol Pharm. 2018; 15 (4): 1403-11. DOI: 10.1021/acs. molpharmaceut.7b00789. PubMed PMID: 29462558.

19. Pfaffl MW. A new mathematical model for relative quantification in real-time RT-PCR. Nucleic Acids Res. 2001; 29 (9): e45. DOI: 10.1093/nar/29.9.e45. PubMed PMID: 11328886

20. Fukumoto Y, Obata Y, Ishibashi K, Tamura N, Kikuchi I, Aoyama K, et al. Cost-effective gene transfection by DNA compaction at $\mathrm{pH} 4.0$ using acidified, long shelf-life polyethylenimine. Cytotechnology. 2010; 62 (1): 73-82. DOI: 10.1007/s10616-010-9259-z. PubMed PMID: 20309632

21. Maass DR, Sepulveda J, Pernthaner A, Shoemaker CB. Alpaca (Lama pacos) as a convenient source of recombinant camelid heavy chain antibodies (VHHs). J Immunol Methods. 2007; 324 (1-2): 13-25. Epub 2007/06/15. DOI: S0022-1759(07)00119-6 [pii] 10.1016/j.jim.2007.04.008. PubMed PMID: 17568607.

22. Benhar I, Reiter Y. Phage display of single-chain antibody constructs. Curr Protoc Immunol. 2002; 10 (10): 9B. DOI: 10.1002/0471142735.im1019bs48. PubMed PMID: 18432867.

23. Studier FW. Protein production by auto-induction in high density shaking cultures. Protein Expr Purif. 2005; 41 (1): 207-34. PubMed PMID: 15915565.

24. Zost SJ, Gilchuk P, Chen RE, Case JB, Reidy JX, Trivette A et al. Rapid isolation and profiling of a diverse panel of human monoclonal antibodies targeting the SARS-CoV-2 spike protein. Nat Med. 2020; 26 (9): 1422-7. DOI: 10.1038/s41591-0200998-x. PubMed PMID: 32651581

25. Liu R, Zhi X, Zhou Z, Zhang H, Yang R, Zou T, et al. Mithramycin A suppresses basal triple-negative breast cancer cell survival partially via down-regulating Kruppel-like factor 5 transcription by Sp1. Scientific reports. 2018; 8 (1): 1138. DOI: 10.1038/s41598018-19489-6. PubMed PMID: 29348684.

26. Simon N, Antignani A, Sarnovsky R, Hewitt SM, FitzGerald D. Targeting a Cancer-Specific Epitope of the Epidermal Growth Factor Receptor in Triple-Negative Breast Cancer. J Natl Cancer Inst. 2016; 108 (8). DOI: 10.1093/jnci/djw028. PubMed PMID: 27075852.

\section{Литература}

1. Pastan I, Hassan R. Discovery of mesothelin and exploiting it as a target for immunotherapy. Cancer Res. 2014; 74 (11): $2907-$ 12. DOI: 10.1158/0008-5472.CAN-14-0337. PubMed PMID: 24824231.

2. Einama T, Homma S, Kamachi H, Kawamata F, Takahashi K, Takahashi N, et al. Luminal membrane expression of mesothelin is a prominent poor prognostic factor for gastric cancer. $\mathrm{Br} J$ Cancer. 2012; 107 (1): 137-42. DOI: 10.1038/bjc.2012.235. PubMed PMID: 22644300.

3. Kelly RJ, Sharon E, Pastan I, Hassan R. Mesothelin-targeted agents in clinical trials and in preclinical development. Mol Cancer Ther. 2012; 11 (3): 517-25. DOI: 10.1158/1535-7163.MCT-110454. PubMed PMID: 22351743.

4. Rump A, Morikawa Y, Tanaka M, Minami S, Umesaki N, Takeuchi M, et al. Binding of ovarian cancer antigen CA125/MUC16 to mesothelin mediates cell adhesion. J Biol Chem. 2004; 279 (10): 9190-8. DOI: 10.1074/jbc.M312372200. PubMed PMID: 14676194.

5. Bharadwaj U, Marin-Muller C, Li M, Chen C, Yao Q. Mesothelin confers pancreatic cancer cell resistance to TNF-alpha-induced apoptosis through Akt/PI3K/NF-kappaB activation and IL-6/Mcl-1 overexpression. Mol Cancer. 2011; 10: 106. DOI: 10.1186/14764598-10-106. PubMed PMID: 21880146.

6. Li M, Bharadwaj U, Zhang R, Zhang S, Mu H, Fisher WE, et al. Mesothelin is a malignant factor and therapeutic vaccine target for pancreatic cancer. Mol Cancer Ther. 2008; 7 (2): 286-96. DOI: 10.1158/1535-7163.MCT-07-0483. PubMed PMID: 18281514.

7. Cheng WF, Huang CY, Chang MC, Hu YH, Chiang YC, Chen YL, et al. High mesothelin correlates with chemoresistance and poor survival in epithelial ovarian carcinoma. Br J Cancer. 2009; 100 (7): 1144-53. DOI: 10.1038/sj.bjc.6604964. PubMed PMID: 19293794.

8. Wang M, Li A, Sun G, Mbuagbaw L, Reid S, Lovrics PJ, et al. Association between mesothelin expression and survival outcomes in patients with triple-negative breast cancer: a protocol for a systematic review. Syst Rev. 2016; 5 (1): 133. DOI: 10.1186/ s13643-016-0313-6. PubMed PMID: 27514374

9. Fougner $\mathrm{C}$, Bergholtz $\mathrm{H}$, Norum JH, Sorlie T. Re-definition of claudin-low as a breast cancer phenotype. Nat Commun. 2020; 11 (1): 1787. DOI: 10.1038/s41467-020-15574-5. PubMed PMID: 32286297

10. Tchou J, Wang LC, Selven B, Zhang H, Conejo-Garcia J, Borghaei $\mathrm{H}$, et al. Mesothelin, a novel immunotherapy target for triple negative breast cancer. Breast Cancer Res Treat. 2012; 133 (2): 799-804. DOI: 10.1007/s10549-012-2018-4. PubMed PMID: 22418702.

11. Lanitis E, Poussin M, Hagemann IS, Coukos G, Sandaltzopoulos R, Scholler N, et al. Redirected antitumor activity of primary human lymphocytes transduced with a fully human anti-mesothelin chimeric receptor. Mol Ther. 2012; 20(3): 633-43. DOI: 10.1038/ mt.2011.256. PubMed PMID: 22127019.

12. Fujiwara K, Masutani M, Tachibana M, Okada N. Impact of scFv structure in chimeric antigen receptor on receptor expression efficiency and antigen recognition properties. Biochem Biophys Res Commun. 2020; 527 (2): 350-7. DOI: 10.1016/j. bbrc.2020.03.071. PubMed PMID: 32216966.

13. Maus MV, Plotkin J, Jakka G, Stewart-Jones G, Riviere I, Merghoub T, et al. An MHC-restricted antibody-based chimeric antigen receptor requires TCR-like affinity to maintain antigen specificity. Mol Ther Oncolytics. 2016; 3: 1-9. DOI: 10.1038/ mto.2016.23. PubMed PMID: 29675462

14. Tillib SV. Prospective Applications of Single-Domain Antibodies in Biomedicine. Mol Biol (Mosk). 2020; 54 (3): 362-73. Epub 
2020/06/04. DOI: 10.31857/S0026898420030167. PubMed PMID: 32492000.

15. Hamers-Casterman C, Atarhouch T, Muyldermans S, Robinson G, Hamers C, Songa EB, et al. Naturally occurring antibodies devoid of light chains. Nature. 1993; 363 (6428): 446-8. DOI: 10.1038/363446a0. PubMed PMID: 8502296.

16. Liu W, Song H, Chen Q, Yu J, Xian M, Nian R, et al. Recent advances in the selection and identification of antigen-specific nanobodies. Mol Immunol. 2018; 96: 37-47. DOI: 10.1016/j. molimm.2018.02.012. PubMed PMID: 29477934

17. Prantner AM, Turini M, Kerfelec B, Joshi S, Baty D, Chames P, et al. Anti-Mesothelin Nanobodies for Both Conventional and Nanoparticle-Based Biomedical Applications. J Biomed Nanotechnol. 2015; 11 (7): 1201-12. DOI: 10.1166/ jbn.2015.2063. PubMed PMID: 26307843.

18. Prantner AM, Yin C, Kamat K, Sharma K, Lowenthal AC, Madrid PB, et al. Molecular Imaging of Mesothelin-Expressing Ovarian Cancer with a Human and Mouse Cross-Reactive Nanobody. Mol Pharm. 2018; 15 (4): 1403-11. DOI: 10.1021/acs. molpharmaceut.7b00789. PubMed PMID: 29462558.

19. Pfaffl MW. A new mathematical model for relative quantification in real-time RT-PCR. Nucleic Acids Res. 2001; 29 (9): e45. DOl: 10.1093/nar/29.9.e45. PubMed PMID: 11328886.

20. Fukumoto Y, Obata Y, Ishibashi K, Tamura N, Kikuchi I, Aoyama K, et al. Cost-effective gene transfection by DNA compaction at $\mathrm{pH} 4.0$ using acidified, long shelf-life polyethylenimine. Cytotechnology. 2010; 62 (1): 73-82. DOI: 10.1007/s10616-010-9259-z. PubMed
PMID: 20309632.

21. Maass DR, Sepulveda J, Pernthaner A, Shoemaker CB. Alpaca (Lama pacos) as a convenient source of recombinant camelid heavy chain antibodies (VHHs). J Immunol Methods. 2007; 324 (1-2): 13-25. Epub 2007/06/15. DOI: S0022-1759(07)00119-6 [pii] 10.1016/j.jim.2007.04.008. PubMed PMID: 17568607.

22. Benhar I, Reiter Y. Phage display of single-chain antibody constructs. Curr Protoc Immunol. 2002; 10 (10): 9B. DOI: 10.1002/0471142735.im1019bs48. PubMed PMID: 18432867.

23. Studier FW. Protein production by auto-induction in high density shaking cultures. Protein Expr Purif. 2005; 41 (1): 207-34. PubMed PMID: 15915565

24. Zost SJ, Gilchuk P, Chen RE, Case JB, Reidy JX, Trivette A, et al. Rapid isolation and profiling of a diverse panel of human monoclonal antibodies targeting the SARS-CoV-2 spike protein. Nat Med. 2020; 26 (9): 1422-7. DOI: 10.1038/s41591-0200998-x. PubMed PMID: 32651581.

25. Liu R, Zhi X, Zhou Z, Zhang H, Yang R, Zou T, et al. Mithramycin A suppresses basal triple-negative breast cancer cell survival partially via down-regulating Kruppel-like factor 5 transcription by Sp1. Scientific reports. 2018; 8 (1): 1138. DOI: 10.1038/s41598018-19489-6. PubMed PMID: 29348684.

26. Simon N, Antignani A, Sarnovsky R, Hewitt SM, FitzGerald D. Targeting a Cancer-Specific Epitope of the Epidermal Growth Factor Receptor in Triple-Negative Breast Cancer. J Natl Cancer Inst. 2016; 108 (8). DOI: 10.1093/jnci/djw028. PubMed PMID: 27075852 